\title{
A economia pastoril e os primórdios do capitalismo na região do Araguaia paraense (1890-1960)*
}

Fábio Carlos da Silva - Professor e pesquisador do Núcleo de Altos Estudos Amazônicos da Universidade Federal do Pará - NAEA/UFPA.

\section{Resumo}

Este artigo sintetiza o processo histórico de ocupação da região do Araguaia paraense no período republicano anterior ao regime militar. Nesse período, predominou na região a economia pastoril de subsistência, com alto grau de autonomia e confinamento regional. Somente durante os períodos do extrativismo da borracha, a região esteve parcialmente integrada ao mercado nacional e internacional para abastecer a indústria de pneumáticos européia e norte-americana (1890-1912 e 1940-1946). O artigo apresenta as principais características econômicas e sociais da região onde se instalariam os grandes projetos agropecuários incentivados pelo Estado brasileiro, que foram os responsáveis pelo início das substanciais transformações econômicas, sociais e ambientais da Amazônia brasileira.

\section{Abstract}

This study analyzes the historical process of occupation in the southern Amazonian region during the republican period before the Brazilian military regime. At that time the main economic activity in the region was the peasantry cattle settlements which presented high economic autonomy and regional isolation. This isolation was partially broken by the rubber extraction in the area which was organized to provide rubber inputs to the North American and European automobile industries. This paper also describes the social and economic characteristics of the region where in the sixty decade of the twenty century the Brazilian Government provided tax incentives to develop cattle projects. The beginning of the substantial environmental and social changes in Amazonia was caused by those projects.

\section{Palavras-chave}

Amazônia, frentes de expansão, economia pastoril.

\section{Keywords}

Amazonia, expansion economic frontier, peasantry cattle economy.

* Este artigo foi elaborado com base em uma pesquisa mais ampla realizada no Núcleo de Altos Estudos Amazônicos (NAEA) sobre a História Econômica e Social da Região do Araguaia Paraense (1890-2005). 


\section{INTRODUÇÃO}

A expansão da pecuária sertaneja de origem nordestina, na última década do século XIX, os dois ciclos de extração do caucho, na primeira metade do século XX, a finalização da rodovia Belém-Brasília e a política de ocupação da Amazônia pelos governos militares, na década de 60 do século XX, representam os marcos do processo histórico de ocupação da região sul oriental da Amazônia Brasileira.

Ao final do governo $\mathrm{JK}$, com a chegada à região da frente pioneira capitalista oriunda do Centro-Sul do país, composta, em um primeiro momento, principalmente por negociantes de terra, madeireiros, fazendeiros, especuladores e aventureiros de toda ordem, tem início o processo de privatização das terras devolutas do Estado do Pará, viabilizado pela associação de interesses desses "empresários da terra" e do governo do Pará. Em um segundo momento, a partir da década de 60, essas terras, já privatizadas, serão vendidas com lucros altamente compensadores para grandes grupos econômicos, nacionais e internacionais, sediados no CentroSul do Brasil, principalmente em São Paulo.

O objetivo deste artigo é fazer um balanço do processo histórico de ocupação da Amazônia sul oriental brasileira, especificamente da região compreendida entre os rios Araguaia e Xingu, sul do Pará, no período que antecede a privatização da maior parte das terras públicas desse Estado, que, na ocasião, faziam parte da área territorial dos municípios paraenses de Conceição do Araguaia e São Félix do Xingu.

Como se verá nas seções deste trabalho, foi somente a partir do final do século XIX que a sociedade nacional, por intermédio das frentes de expansão, passou a penetrar os campos da margem esquerda do rio Araguaia na orla da fronteira paraense. No período de 1890 a 1960, praticamente o que predominou na região foi a economia camponesa pastoril, permeada pelos dois ciclos extrativistas do caucho. Apenas na época áurea da borracha é que a organização social da produção de predominância campesina subordina-se à economia extrativista mercantil gomífera.

Verifica-se, assim, o domínio aparente do capital comercial sobre o modo de produção camponês. Aparente, no sentido de domínio indireto, pois, na verdade, quem subordina tanto o capital comercial, representado pelos seringalistas, pelas casas aviadoras e pelas casas exportadoras, quanto a atividade extrativa, representada pelos caucheiros, no caso de nossa área de estudo, é o capital industrial, representado pelas empresas produtoras de artefatos de borracha. É ele, portanto, quem determina a maior ou menor mobilização do capital comercial. Igualmente, estabelece o ritmo da produção, provoca o surgimento e o desaparecimento de corrutelas, povoados e cidades, na área envolvida no circuito da produção e comercialização, e é o fator principal na determinação dos fluxos migratórios, concernentes às frentes de expansão da sociedade nacional. 
Foi também somente naquele período que houve uma relativa monetarização da economia local. Detectou-se na pesquisa que a área estudada sempre serviu de ponto de apoio ao capital industrial, ainda que de maneira indireta e implícita. Nos locais em que hoje estão situadas as principais cidades do Sul do Pará, existiram povoados sertanejos que serviram de pontos de apoio para o descanso e o reabastecimento das tropas de muares que faziam o transporte da borracha dos cauchais do Xingu até Conceição do Araguaia.

Durante o período da exploração do caucho, esses povoados sertanejos abastecidos pela economia camponesa regional, ao servirem de infra-estrutura para o capital comercial, estavam, na verdade, contribuindo para a acumulação do capital industrial, na medida em que o caucho era utilizado como matéria-prima para a indústria de artefatos de borracha das economias centrais nascentes.

\section{A conversão das terras indígenas em fronteira camponesa}

No princípio, as terras e matas da atual região do Araguaia paraense eram habitadas e exploradas somente pelos índios. Antes da chegada dos primeiros criadores maranhenses aos campos naturais dos rios Pau D'Arco e Arraias, principais afluentes da margem esquerda do rio Araguaia no Sul do Pará, lá viviam os índios Kayapó. Pertencentes à ramificação das tribos de língua Jê e, por causa do sistema de vida essencialmente nômade que levavam, habituados às constantes correrias pela zona dos rios Araguaia e Xingu, evitando ou mesmo revidando os constantes ataques dos colonizadores, os Kayapó constituíram diferentes aldeias nos locais em que estiveram.

Na região estudada (Figura 1), existiam três grupos ou subtribos Kayapó: os Kradaú ou Irã Aimrare, atualmente extintos, habitavam os campos naturais de Conceição do Araguaia, que se estendiam desde as orlas do rio Arraias, passando pelo Pau D'Arco e indo até os começos da mata geral do Xingu, e eram assistidos pela missão dominicana pioneira da fundação da cidade de Conceição do Araguaia ; os Gorotire, pacificados em 1936, hoje vivem em sua grande maioria no Posto Gorotire, situado às margens do rio Fresco, afluente do Xingu, em contato permanente com os civilizados; os Kuben-Kran-Kegn, pacificados em 1952 (BELLIZI, 1958, p. 141-143), vivem atualmente nas proximidades da cachoeira da fumaça, formada pelo Riozinho, afluente do rio Fresco.

A área de campos naturais, que vai da margem esquerda do Araguaia até o início da floresta amazônica e que era habitada pelos Kradaús, foi transformada, ao longo da última década do século XIX, em fronteira camponesa, no começo com a utilização dos índios nessa conversão das terras tribais em terras camponesas e posteriormente com a extinção deles pelo colonizador.

\footnotetext{
${ }^{1}$ Sobre a história social e econômica de Conceição do Araguaia ver: Ianni, 1978 e Luz, 2004.
} 
Esse processo foi facilitado porque os índios desse grupo estavam acostumados ao trato com neobrasileiros desde a fundação, em 1859, da missão dominicana de Santa Maria Nova, localizada à margem direita do Araguaia, bem em frente à cidade de Conceição do Araguaia - atual Couto Magalhães (TO); esses índios foram alunos do Colégio Isabel, fundado na década de 70 do século XIX, pelo então governador da Província de Goiás, General Couto Magalhães.

Assim, no último quartel do século XIX, penetrações sucessivas foram feitas nos campos que se prolongam por todo o curso do Arraias e fazem junção com as pastagens naturais do Pau D'Arco. Os trilhos dos indígenas foram as primeiras estradas boiadeiras, e suas aldeias, disseminadas pelo Arraias e pelo Pau D'Arco, as primeiras fontes de suprimento e bases de fixação nos campos do interior.

Esse processo intensificou-se principalmente na década de 90 do século XIX, com a vinda de muitos maranhenses que habitavam a região de Pastos Bons (Boa Vista e Grajaú) e que se deslocaram em grande número para a margem paraense do Araguaia, pressionados, entre outros fatores, pelas animosidades políticas que imperavam em Boa Vista (atual Tocantinópolis) (VELHO, 1972). Essas divergências diziam respeito à questão de limites entre os Estados de Goiás e Maranhão e eclodiram a partir da proclamação da República em 1889.

Sem se pretender detalhar esse processo, importa salientar que, na última década do século XIX, muitas famílias maranhenses engajadas na atividade pecuária atravessam o rio Araguaia e, depois de permanecerem algum tempo nas margens desse rio, junto do núcleo catequético de Conceição do Araguaia, fundado por frei Gil de Vila Nova em 1897, vão estabelecer-se nos campos do Pau D'Arco. Para oeste, em imediata sucessão aos campos naturais, "havia a chamada mata geral do Xingu, desabitada de 'cristãos' e impenetrável" (MOREIRA NETO, 1960, p. 14).

Nos campos do Pau D'Arco, o movimento ganha corpo e expandese. O próprio estrangulamento das vias de acesso aos mercados consumidores contribui para o crescimento dos rebanhos. O confinamento a que se sujeita a economia pastoril evita a diminuição dos rebanhos, pela retirada freqüente de boiadas dirigidas aos centros de consumo. $\mathrm{O}$ desestímulo provocado pelo isolamento e pela falta de mercados para colocar o produto não foi, até o desenvolvimento do primeiro ciclo do caucho, um fator que impediu a ampliação das atividades pastoris, pois, sendo a região de campos naturais, naquele momento, a pecuária era a única forma de produção economicamente viável.

Assim, "toda a área tribal ocupada pelos Irã-Amráire Kayapó foi convertida em pastagens. Suas roças usuais nas matas ciliares dos rios Arraias e Pau D'Arco foram ampliadas e postas a serviço da frente 


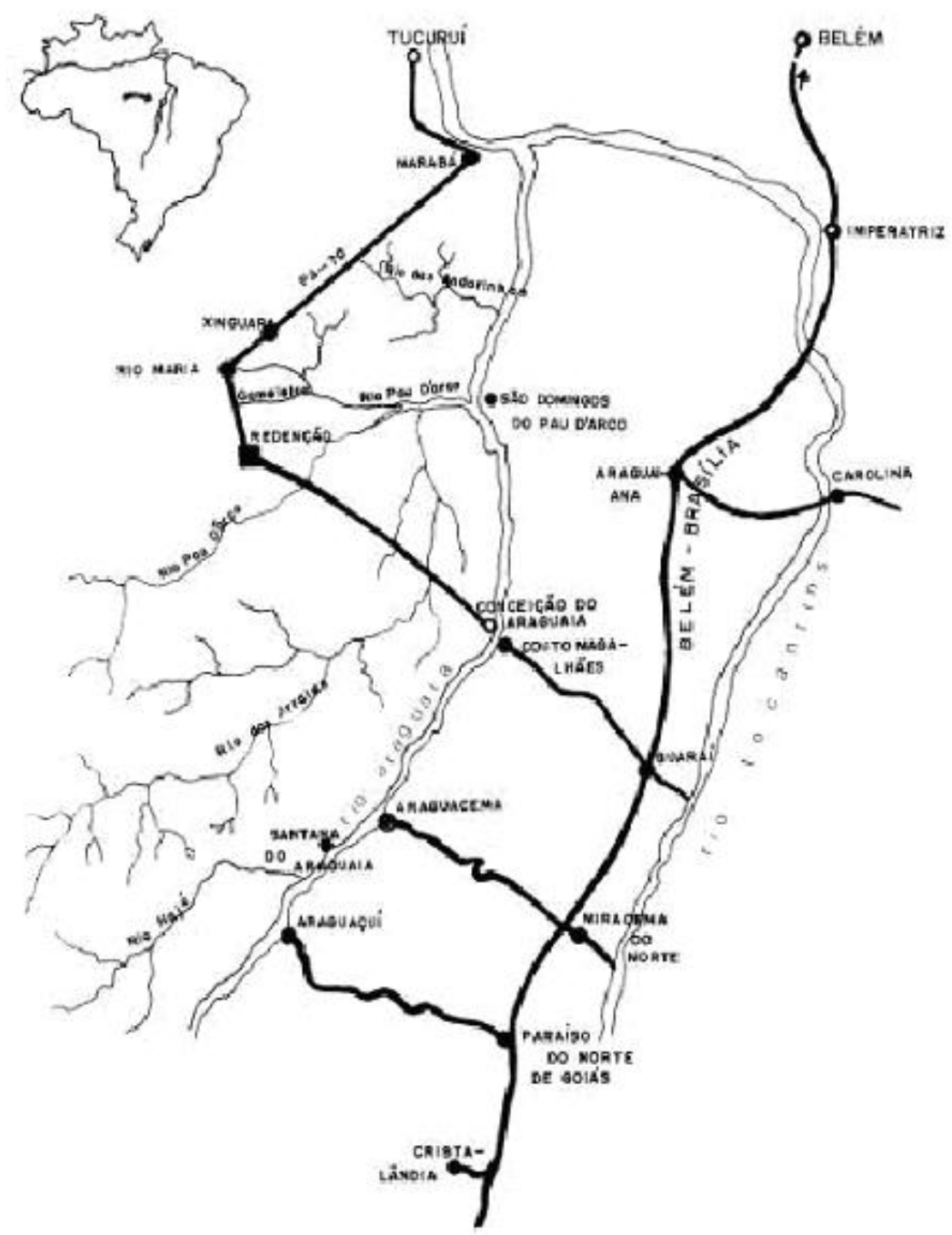

expansionista" (MOREIRA NETO, 1960, p. 12).

Figura 1: Região da Pesquisa.

À medida que as terras indígenas são transformadas em área camponesa, onde se pratica uma pequena lavoura de subsistência e não se registra a presença da moeda, muda também o modo tribal de existência, que passa a depender da economia pastoril. Esse processo de mudança cultural dos povos tribais está relativamente documentado pela etnologia e não cabe aqui entrar em pormenores. O importante a salientar é que, progressivamente, a cultura tribal é transformada, absorvida e, na maioria das vezes, destruída pela frente colonizadora.

Os Kradaús, que viviam na região há muitos séculos, de súbito foram substituídos pelos novos donos do lugar, os fazendeiros e vaqueiros maranhenses. Em pouco tempo, o território dos campos estava vazio de índios. 
A maioria deles foi atraída pelos dominicanos para o núcleo urbano de Conceição (IANNI, 1978, p. 15), e os remanescentes, provavelmente, foram envolvidos pela onda pastoril. As duas tribos restantes foram, no decorrer do século XX, confinadas em reservas indígenas pelo Serviço de Proteção ao Índio (SPI) - atualmente Fundação Nacional do Índio (FUNAI).

\section{As Frentes de Expansão da pecuária nordestina e a ocupação da amazônia sul oriental}

Foi a atividade pecuária que quebrou o isolamento da vida econômica e social dos índios Kaiapó nos campos de Conceição. Essa frente pastoril, que invade os sertões do Araguaia paraense, pode ser entendida como um prolongamento do processo secular de ocupação dos sertões nordestinos, cuja causa é a não convivência do gado com a atividade agrícola. Além disso, o empobrecimento do solo, provocado pela renovação das pastagens, a ocorrência de grandes estiagens e a formação de latifúndios nas zonas de pastoreio mais antigas também contribuem para o deslocamento dos criadores de gado nordestinos, que, partindo do litoral, vão cada vez mais se embrenhando nos sertões brasileiros.

Estava em jogo o interesse da oligarquia rural dominante, que necessitava de grandes glebas de terra para manter e reproduzir o modelo primário exportador. Como não existia o arame, era impossível o consórcio da monocultura exportadora com a pecuária, uma vez que o gado invadia e destruía as plantações de cana-de-açúcar, de algodão e de outros produtos primários demandados no mercado internacional.

A condição básica para a dilatação e a expansão do sistema econômico pecuarista nordestino foi a disponibilidade de terras. À medida que os solos se tornavam improdutivos para a formação de novas pastagens e, conseqüentemente, para a sobrevivência do gado, os rebanhos penetraram rapidamente o interior, cruzando o São Francisco, alcançando o rio Tocantins e o Maranhão nos começos do século XVIII (FURTADO, 1977, p. 58).

O sistema de partilhas, que caracterizava as relações de produção estabelecidas entre o fazendeiro e os vaqueiros, e o distanciamento do litoral, que tornava o gado mais oneroso, faziam com que a economia pastoril tendesse a fechar-se sobre si mesma numa atividade de autosubsistência. Explica Moreira Neto (1960, p. 6):

Voltada para si mesma e para a solidão dos enormes territórios que ocupa, a criação de gado, sem contar com a participação mais íntima no comércio e nas fontes de riqueza da colônia, tende a desenvolver um sistema de economia fechada, auto-suficiente, em que as trocas em espécie se avultam em importância sobre a circulação de moeda.

E acrescenta o autor: 
além da pecuária, havia uma tímida lavoura de subsistência, praticada nas vazantes ou nas matas ciliares que bordejam os cursos d'água permanentes. Esta fornecia ao sertanejo um mínimo de produtos agrícolas indispensáveis a sua manutenção e à dos animais de transporte: mandioca, milho, feijão, cana. Eram diminutas em extensão; as roças individuais dificilmente ultrapassariam a área de um hectare, em que geralmente só se plantava uma vez (MOREIRA NETO, 1960, p. 7).

A frente pastoril que parte da região dos Pastos Bons no sul do Maranhão e que vai avançar até os campos de Conceição do Araguaia, teve origem na Bahia, atingindo o sul do Maranhão em meados do século XVIII. A partir daí, iniciar-se-ia o avanço para o Tocantins (VELHO, 1972, p. 24).

Essa frente decorre da estrutura econômica do país, que determina o modo e os interesses pelos quais novas áreas são incorporadas à sociedade nacional. Tem lugar então um alargamento da fronteira camponesa pastoril, originária do sistema primário exportador, que agora parte do Maranhão, atravessa o Tocantins, ocupando rapidamente as terras compreendidas entre esse rio e o Araguaia, e, nos anos finais do século XIX, atinge a própria margem esquerda desse último rio.

Estava, portanto, iniciado o processo de povoamento da área, e a frente pecuária é que, a princípio, ditaria a forma da atividade produtiva que se instalaria nos campos paraenses do Araguaia. A frente pecuarista que há mais de trezentos anos partira do litoral baiano palmilhando todo o sertão nordestino atinge sua expressão máxima ao chegar à Amazônia Oriental, cruzando os dois grandes rios que poderiam ter obstruído sua marcha - Tocantins e Araguaia - e estabelecendo-se nos campos paraenses do Arraias e Pau D'Arco. Somente a grande floresta, com sua hiléia quase instransponível para a tecnologia sertaneja, foi capaz de deter sua marcha pelo interior brasileiro.

No final do século XIX, o isolamento a que estavam sujeitos os fazendeiros do baixo Pau D'Arco, embora a princípio tenha concorrido para o crescimento do número de cabeças bovinas, começa a contribuir para a inviabilidade da fixação dos criadores no lugar, tornando-se fator de uma provável impermanência, que certamente teria ocorrido se não fosse a presença do caucho nas matas contíguas aos cerrados pastoris, que emergiam em abundância até as margens do rio Xingu.

Com efeito, o gado criado no lado paraense do Araguaia encontrava sérias dificuldades de comercialização devido à não existência de uma tecnologia adequada que possibilitasse a travessia dos rios Araguaia e Tocantins, sem diminuir ou inutilizar o rebanho negociado. Explica Iglésias (1958, p. 575):

Para os compradores de gado que vão de Piauí a Maranhão, o gado que está na margem oposta do Tocantins quase não 
convém, pois as reses que atravessam o rio ficam estropiadas e com muito custo endireitam. Se não descansarem numa boa invernada, não 'botam' até as feiras. Além disso, na travessia do rio, muitas delas morrem, e é preciso, também, pagar os homens que são especializados nesse serviço.

Portanto, as perdas eram duplas, pois, além do Tocantins, havia o Araguaia a separar o segmento camponês criatório, situado nos cerrados paraenses, do mercado litorâneo. Para o sul, onde se desenvolvia aceleradamente um mercado interno urbano, em conseqüência da ampliação da área plantada cafeeira - cujo produto, em meados do século do XIX, passa a comandar a reprodução do capital nacional -, o acesso era problemático. Além do mais, esse mercado já era suprido pelo gado goiano e mineiro, o que tornava, devido às longas distâncias a percorrer, as vantagens comparativas desfavoráveis para o rebanho paraense.

Por esses motivos, tentavam-se contatos com Belém, apesar da distância e da dificuldade de navegabilidade em alguns trechos do Araguaia e do Tocantins. Fluvialmente, por causa da característica do produto, era impraticável a colocação do gado no mercado de Belém, e a inexistência de demanda teria, como já se disse, certamente levado a pecuária local à derrocada.

É precisamente nessa ocasião que o desenvolvimento das economias centrais leva à necessidade da utilização da borracha como matéria-prima industrial, o que foi providencial para os criadores do Pau D'Arco, pois, nas matas contíguas a seus pastos, encontrava-se a fonte daquela matériaprima, o que possibilitou a formação de um mercado local para a produção pecuária dos campos do Araguaia paraense.

\section{O ciclo extrativista do caucho e a subordinação da pecuária}

No último quartel do século XIX, cresceu bastante a procura da borracha no mercado internacional, principalmente após 1890, com o aperfeiçoamento da câmara de ar, patenteada por Dunlop na GrãBretanha, em 1888. Com isso, passou-se a uma grande utilização da bicicleta, vindo depois a difusão dos veículos motorizados.

A necessidade, então, do suprimento da goma por parte das indústrias de artefatos de borracha dos países europeus cresceu significativamente. Porém, ressalta Magalhães Filho (1975, p. 378-379):

a única região produtora era a Bacia Amazônica, e praticamente toda a produção cabia ao Brasil, pois a participação boliviana nunca alcançou mais de 10\% do total. Sua produção era feita por simples extração, nas grandes propriedades dos seringalistas, que geralmente viviam em Manaus ou Belém, mantendo administradores ou capatazes nos seringais. 
É nesse contexto que se insere a região do Araguaia paraense como fornecedora de produtos primários demandados no mercado internacional. A existência do caucho na mata geral que vai dos campos até o Xingu levou para a área grandes quantidades de migrantes que não conseguiam condições favoráveis para se manterem nas zonas nordestinas de ocupação mais antiga. Tratava-se agora, não de trabalhadores acostumados com a vocação pastoril, mas de camponeses em geral, que, como extratores da borracha, vieram juntar-se aos primeiros, na esperança de uma vida melhor.

Rapidamente a economia regional ganha um novo impulso, pois, além de grandes levas de migrantes, que se transformariam em caucheiros, instalam-se na região os aviadores comerciais, que se encarregavam do financiamento e do transporte da produção e dos víveres. Os donos dos instrumentos de comercialização efetivamente dominavam o comércio dos campos, pois, dadas as distâncias que se teriam de percorrer até chegar a Belém, ponto de repasse da borracha para o exterior, só quem tivesse algum capital que viabilizasse a circulação do caucho, além da parcela destinada aos gastos com mantimentos e instrumentos de produção do caucheiro, poderia ter algum sucesso.

O dinheiro passa a fazer parte das relações de produção locais, antes embasadas no escambo. Estava em curso a transformação da fronteira camponesa pastoril de subsistência em fronteira camponesa extrativista mercantil. O capital comercial que adentrava nos campos do Pau D'Arco passa a subordinar o segmento pecuário de subsistência, como este havia subordinado a cultura tribal.

Nos campos, onde hoje estão situadas as principais cidades do Sul do Pará - Redenção, Pau D'Arco, Rio Maria, Xinguara -, como nas matas, onde se localizam as terras privatizadas pela Companhia de Terras da Mata Geral, no começo do século XX, o movimento foi intenso. Tanto em uma área como em outra se localizaram povoados sertanejos que serviam de ponto de apoio para os comboios que se dirigiam aos locais de extração da goma. Na pesquisa de campo, detectamos que, no local onde hoje é o cemitério da cidade de Redenção, outrora existiu uma corrutela denominada Solta.

Nesse povoado sertanejo que ficava na boca da mata, isto é, no início da estradinha que levava, pela floresta, aos cauchais da beira do Xingu, as tropas carregadas de caucho estacionavam com a finalidade de descanso e reabastecimento de víveres, para, posteriormente, seguir viagem até Conceição do Araguaia. Nessa localidade, a borracha era acondicionada em batelões e, por via fluvial, descia o Araguaia e o Tocantins, até Belém do Pará. Finalmente, as casas exportadoras encarregavam-se de fazê-la chegar às portas das indústrias européias. Frei José Maria Audrin (1946, p. 85) descreve bem esse período de transformações no lugar:

Atraídas pela presença dos missionários e pela miragem de terras novas, muitas famílias afluíram sem cessar dos 
sertões de Goiás, Maranhão e Piauí. Uma outra causa de transformação rápida e inaudita era a descoberta, em 1904, de uma riquíssima zona de 'borracha' nas matas vizinhas. Chegaram logo às centenas os exportadores da preciosa goma castilhoa. Conceição tornou-se um dos importantes centros caucheiros da região Amazônica, sobretudo após o encontro nas florestas dos seringueiros do Araguaia com os do Xingu. Era um movimento incessante de tropas chegando de todas as direções.

E mais adiante completa o missionário:

As estradas que levavam às matas da 'borracha' passavam infelizmente junto das aldeias das Arraias e do Pau D'Arco, que se tornaram em breve o ponto de pouso obrigatório para as caravanas de caucheiros. Os campos das Arraias viam multiplicarem-se os sítios e as fazendas. As próprias matas do caucho iam sendo ocupadas. Em cada passagem de ribeirão, em cada cabeceira, em cada campestre, fixavam-se moradores, animados pelos fartos lucros provenientes do trânsito ininterrupto de seringueiros. A conseqüência inevitável foi a formação rápida de numerosos núcleos mais ou menos importantes: Santo Antônio, da Solta e São Pedro, da Gameleira, nas orlas da mata geral; Triunfo, no centro da mesma; Novo Horizonte, já nas beiras do rio Fresco; Nova Olinda, na foz do Riozinho; São Félix, enfim, na margem direita do Xingu (AUDRIN, 1946, p. 95).

É importante frisar que essas corrutelas surgidas no auge da exploração do caucho na área pesquisada tiveram um papel relativamente importante no ciclo extrativista local. Embora, na sua maioria, tenham perdido grande parte de seus habitantes quando cessou a atividade extrativista, durante esse período serviam como ponto de apoio ao trânsito mercantilista do caucho.

Todavia, a atividade extrativista na região durou menos de uma década, pois, apesar do progressivo incremento da procura por borracha, mesmo com grande aumento nos preços, não houve investimento em tecnologia para aumentar a produtividade dos seringais e cauchais da Amazônia. Além disso, a Inglaterra, principal interessada no produto, desde finais do século XIX já iniciara o plantio de seringueiras em suas colônias da Malásia e do Ceilão, assim como também a Holanda, em Sumatra e Bornéu.

O aumento da demanda internacional no primeiro decênio do século XX pôde ser atendido, de início, pela borracha amazônica, com o simples aumento da mão-de-obra, mas estimulou ainda mais os plantadores europeus do Oriente, e sua plantação aumentou rapidamente (ver Tabela 1).

Com o aumento crescente da produção asiática, os preços caíram vertiginosamente, e a produção dos cauchais do Araguaia e do Xingu, como de toda a Amazônia, entrou em profunda decadência. A vida nos 
campos e na mata volta a ter um isolamento incomum. Regressa o escambo como forma de trocar o parco excedente produzido, o dinheiro não mais se fará presente na região nos níveis de outrora, até que se inicie, por volta de 1960, o desenvolvimento do processo que transformaria radicalmente a natureza e a sociedade do lugar.

Tabela 01: Produção mundial de borracha (em toneladas).

\begin{tabular}{c|rrr}
\hline \multirow{2}{*}{ PERÍODO } & \multicolumn{2}{|c}{ ZONAS PRODUTORAS } \\
\cline { 2 - 4 } & \multicolumn{2}{|c|}{ BRASIL } & \multicolumn{1}{c}{ PRODUTORES ASIÁTICOS } \\
\hline 1905 & 35.000 & 146 \\
1910 & 38.104 & 8.230 \\
1913 & 36.615 & 47.000 \\
1917 & 39.000 & 210.000 \\
\hline
\end{tabular}

Fonte: Magalhães Filho (1975, p. 214).

Mas, antes desse período, os moradores locais ainda experimentariam um novo e também breve surto econômico durante a Segunda Guerra Mundial, quando o governo brasileiro assinou com os Estados Unidos os "Acordos de Washington", instituindo a política conhecida como Batalha da Borracha . Entretanto, o impacto na economia local foi muito menos relevante que o do começo do século, e, a partir de 1946, ano da derradeira carga de borracha das matas do Xingu, a área transformar-se-ia novamente em fronteira camponesa pastoril, produtora de valores de uso.

\section{Estagnação econômica e isolamento regional}

No período que se segue à estagnação da economia extrativista, a fazenda criatória volta ser a principal unidade de produção e consumo nos campos do Pau D'Arco. O despovoamento da região, principalmente depois de 1912, deixou um saldo muito baixo de moradores nos arredores do local onde futuramente se instalaria a frente pioneira de Redenção, hoje a principal cidade do Sul do Pará.

Já por ocasião da segunda onda extrativista da borracha, os moradores do lugar eram muito poucos e dispersos pelas redondezas. Na pesquisa de campo, foram coletados alguns depoimentos de moradores antigos do local - alguns deles nascidos e criados nos campos do Pau D'Arco -, que permitiram reunir as informações referentes a essa época que a seguir são arroladas.

O povoamento era escasso. A borracha era extraída da atual fazenda Bannach até às beiras do rio Xingu e era levada para Conceição do Araguaia no lombo dos burros, exatamente como era feito quando do primeiro ciclo do caucho. Por volta de 1946, ano da última carga de borracha coletada nas matas contíguas às fazendas criatórias, os conflitos entre os caucheiros e os índios Kayapó-Gorotire atingiam proporções tais que a vida para os habitantes era bastante difícil.

${ }^{2}$ Sobre a Batalha da Borracha ver: Martinello, 1988:23-61 
O número total de pessoas residentes nas fazendas pastoris e nas imediações dos campos naturais totalizava, em 1948, entre vaqueiros, fazendeiros, sitiantes e marreteiros, 208 pessoas. Nesse ano, no lugar onde futuramente seria erguida a vila de Redenção, não existia ninguém residindo.

Devido à rarefação e à dispersão dessa população, e aos conflitos existentes entre os coletores do caucho e os índios, o que levou esses últimos a se insurgirem contra qualquer habitante "cristão", as famílias camponesas não se fixavam isoladamente num determinado sítio, juntando-se em grupos de quatro ou cinco, para melhor "se defenderem dos Kaiapó-Gorotire". A princípio, os índios não atacavam os "cristãos"; mas, por volta de 1920, um bando de jagunços começou a matar os índios bem na beira do rio Arraias, o que fez com que daí em diante eles se revoltassem e passassem a não mais distinguir os pistoleiros dos criadores de gado. Esses jagunços tentaram também saquear as moradias e criações dos habitantes do Pau D'Arco, mas não tiveram sucesso, porque os moradores andavam todos armados e revidaram o ataque. Posteriormente o bando foi liquidado pela tribo inicialmente agredida.

Os únicos meios de transporte utilizados pelos moradores dos campos eram o cavalo e o jumento - este para o transporte de cargas. O tempo despendido na viagem era de aproximadamente 10 dias, sendo cinco dias de ida e cinco dias de volta. Essas viagens eram muito raras e limitavam-se ao suficiente para abastecer os criadores dos produtos que não eram produzidos pela família, principalmente sal, querosene, fósforo e munições. Mesmo assim, a oferta dessas mercadorias não era satisfatória, e os criadores locais perdiam alguns dias em Conceição à espera dos produtos, ou de um deles.

A economia era essencialmente de subsistência, pois não havia, até 1950, aproximadamente, um mercado significativo para o gado ou seus subprodutos. Alguma carne seca era colocada nos garimpos próximos à vila do Pau D'arco, localizada na margem goiana do Araguaia, mas não atingia maiores proporções. A partir de 1950 começam a ensaiar-se os primeiros transportes de carne da região para o mercado de Belém. Isso se deveu à instalação de uma charqueada na cidade de Araguacema, situada um pouco acima de Conceição do Araguaia, na margem do Estado de Goiás. Esse fato parece ter tido uma grande importância para a pecuária do Pau d'Arco, pois, a partir de então, o gado começa a ter colocação.

O fato de o gado ser transportado para Belém por via aérea, o que onerava o custo da produção, era compensado pelo baixo valor despendido pela charqueada na remuneração dos criadores.

O rebanho era criado solto nos campos. A abundância de pastos naturais era um fator positivo para o seu crescimento e sua reprodução. As roças eram feitas em regime de mutirão e não se localizavam perto das habitações, pois os sertanejos escolhiam as melhores terras para a lavoura e as menos próximas dos pastos. Em geral distanciavam-se uns dois a três quilômetros do núcleo residencial. 
Para assentar o roçado, os camponeses, depois de determinar o lugar ideal para tal, munidos de machados e facões - não existia a foice naquele tempo na região -, inicialmente construíam um pequeno rancho, para depois proceder à derrubada, à queima da mata e ao plantio. Em seguida, cercavam o local para que os porcos não penetrassem e comessem a plantação. A cerca era constituída de três ou quatro pedaços de pau dispostos em paralela e de estacas verticais pouco espaçadas, para que o gado também não penetrasse. Os principais produtos cultivados eram: arroz, mandioca, macaxeira, milho, fava, algodão e feijão de corda.

\section{A conomia pastoril nos campos do Pau D'Arco}

É interessante notar que a vida econômica nos campos do Pau D'Arco até 1960 era essencialmente organizada para a produção de valores de uso. O comércio, como já se disse, era reduzidíssimo, limitando-se às viagens esporádicas que os criadores empreendiam até Conceição do Araguaia, onde trocavam alguma carne seca ou mesmo peles de veados pelas mercadorias de que estavam necessitando. $\mathrm{O}$ dinheiro era utilizado somente como intermediário nessas poucas relações mercantis. Para conseguir alguma moeda, os criadores pastoris, no começo do inverno, matavam o gado, secavam a carne, preparavam alguns fardos e seguiam para comercializá-la em Conceição.

Além das peles e da carne bovina, também era comercializada uma pequena quantidade de toucinho de porco salgado. Geralmente se levavam, em cada viagem, de quatro a cinco jumentos carregados com esse excedente produzido. No mercado de Conceição, o produto era vendido aos poucos habitantes locais, geralmente funcionários públicos, eclesiásticos, comerciantes varejistas e demais moradores em geral. Com o dinheiro obtido, comprava-se algum instrumento para a lavoura e a pecuária, querosene, fósforo e sal.

Já se disse das dificuldades em encontrar esses produtos essenciais para a família camponesa. O sal era comprado em quantidade suficiente para que se pudesse passar o inverno, época das chuvas, pois nesse período o rio Arraias enchia demais, dificultando a passagem das tropas que demandavam Conceição ou a atual zona de Redenção, quando de seu regresso. Isso devido ao fato de o caminho existente ser cortado por aquele afluente do Pau D'Arco.

Do começo do século até 1945, aproximadamente, os sertanejos, ao chegar à beira do rio Arraias, descarregavam todos os animais e atravessavam-nos a nado para a outra margem do rio, tanto na ida, quando levavam a carne, quanto na volta, quando traziam os produtos que não fabricavam, principalmente o sal. A partir de então, os criadores dos campos do Pau D’Arco construíram um "ajolo" (espécie de ponte, suportada por duas cordas grossas, que atravessava de uma margem à outra), pelo qual os burros transpunham o Arraias, mas a carga continuou a ser desatrelada e transposta manualmente de uma margem à outra. 
Outro produto também cultivado na região, que futuramente sediaria a frente pioneira de Redenção, era a cana-de-açúcar. Com ela os sertanejos fabricavam a rapadura, não tendo, portanto, necessidade de comprar açúcar, e também produziam a cachaça.

O processo de fabricação desses produtos comportava uma tecnologia que empregava tanto a força de trabalho quanto a tração animal. O engenho era fabricado de madeira e na moagem da cana era necessário o emprego de três pessoas. Primeiro, uma delas, ainda de madrugada, encarregavase de amansar os bois e conduzi-los ao engenho, atrelando-os às correias da moenda. Em seguida, tinha início a moagem da cana. O segundo trabalhador colocava a cana na moenda, e o terceiro aparava-a do outro lado, sendo o primeiro também encarregado de tanger os bois. Finalmente, após a obtenção do caldo, era produzida a rapadura e a aguardente.

A cachaça era tomada em pequenas cumbucas feitas de barro e era servida gratuitamente por todos os criadores mutuamente. Nada era vendido entre os membros da comunidade pastoril local. Quando acontecia, por exemplo, de um chefe de família necessitar de produtos que não fossem fabricados na economia local, e se ele não possuísse um excedente bovino para trocar pelos produtos, os membros da comunidade que tivessem mais excedentes emprestavam o gado ao primeiro, para receberem posteriormente, quando os novilhos dele já tivessem crescido.

Acentua-se mais ainda o nível de subsistência do segmento pastoril local, quando se constata que as roupas utilizadas pelos criadores dos campos eram provenientes do artesanato camponês doméstico. Para tal, inicialmente se fabricavam os teares manuais, também de madeira, por meio dos quais, numa fase posterior, as mulheres dos sertanejos, empregando o algodão colhido nas roças, confeccionavam as camisas, as calças, as cobertas e os vestidos da família camponesa.

Os criadores do Pau D'Arco, na época da formação do roçado, ajudavam-se mutuamente num sistema de mutirão. Ademais, principalmente após os conflitos entre os tiradores de borracha e os povos tribais da mata geral, por ocasião da Segunda Guerra Mundial, temia-se constantemente um possível ataque por parte dos Kayapó-Gorotire. Com isso, ou também por isso, os sertanejos do pastoreio agregavam-se nas atividades da lavoura, porque, se andassem ou trabalhassem isoladamente, poderiam ser mortos pelos índios. Um habitante da periferia da cidade de Redenção, nascido e criado nos campos do Pau D'Arco, relembra essa época:

O pessoal se ajuntava pra trabalhar junto porque se trabalhasse só um, o índio matava. A gente ia pra roça ou pra qualquer um serviço, só com arma, porque ninguém andava desarmado. Chegava lá, não encostava ela num pau pra ficar em pé. Tinha que botar a arma deitada no chão, porque se botasse ela em pé o índio chegava e apanhava. 
Foi desse modo que, passada a segunda fase de extração do caucho, nas matas da região do Araguaia paraense, a economia local voltou a ser definida pelo empreendimento pastoril de subsistência, embasado na produção de valores de uso; secundariamente, produzia-se algum excedente para obter bens que suprissem as necessidades dos moradores do lugar. Em meados da década de 40 do século XX, os habitantes passaram a utilizar a moeda para permutar seus produtos, mas em escala reduzida. Afora essa época e excetuando-se igualmente os primeiros 15 anos do século, predominaram as trocas em espécie na sociedade do Pau D'Arco.

\section{$6 \mathrm{O}$ isolamento dos sertanejos do Araguaia}

Os criadores pastoris viviam quase em um confinamento permanente. Um ou outro marreteiro palmilhava a região esporadicamente permutando fósforos, querosene, utensílios domésticos e quinquilharias em geral, por toucinho de porco, carne seca e peles de animais silvestres. Esses marreteiros percorriam os campos, levando a mercadoria a ser comerciada no lombo dos burros, mas a freqüência das viagens era irrelevante. Por ocasião do inverno, quando as águas do rio Pau D'Arco atingiam um determinado nível que permitisse a navegação, alguns regatões aportavam com suas pequenas embarcações em alguma corrutela situada à margem do rio. Mas, como, além do frágil mercado constituído pelo segmento pastoril, os preços eram aviltados pelos gastos com combustível do motor, os regatões também mantinham um comércio insignificante.

O grau de isolamento da população local transparece no depoimento de outro informante, que também habitava os campos na época:

"Aqui às vezes a gente passava vinte, trinta dias sem ver outra pessoa. Só via os da casa mesmo. Os vizinhos moravam distante uma légua; via como é que estava, via se ainda estava vivo ou se os índios já tinham matado. Aqui, a vida era pesada mesmo".

Apesar do parco comércio e do semi-isolamento dos criadores de gado, a qualidade de vida parecia ser bem melhor do que aquela que experimentariam os poucos remanescentes da economia pastoril cerca de vinte anos mais tarde. Um deles, despojado de suas terras após a instalação da frente pioneira de Redenção, e em 1978 vivendo de um pequeno comércio na cidade, revela:

Aqui, a vida de primeiro era difícil por causa do movimento que não tinha. Mas no que diz respeito à comida, era farto demais. Matava um gado e não tinha pra quem vender. $\mathrm{O}$ pessoal morava longe demais um do outro. Quando vinham era pra tomar emprestado, chegavam em casa e falavam: "Oh compadre! Cê me empresta aí tantos quilos de carne do seu gado que você matou que quando eu matar o meu eu te pago!" E a gente emprestava. Era assim. Ninguém vendia. 
Como se vê, a fartura era abundante e o comércio, reduzidíssimo, não se registrando a circulação da moeda entre as unidades de produção pastoris. Cada unidade criatória era, ao mesmo tempo, unidade de produção e de consumo. Os membros da família fabricavam quase tudo aquilo de que necessitavam. Havia roças das quais obtinham legumes e cereais que, juntados à carne bovina, formavam a base da dieta alimentar da família sertaneja. Galinhas e porcos, somados à carne de caça, propiciavam uma constante diversificação na alimentação. Às vezes, também se praticava alguma pesca. O açúcar, como já frisado, era produzido internamente.

Por outro lado, o artesanato doméstico rural garantia o suprimento da indumentária familiar, e a cachaça também provinha dos engenhos locais. A banha animal fazia as vezes de óleo industrial, o que elevava ainda mais o grau de auto-suficiência da economia pastoril instalada na área estudada. Os criadores constituíram, portanto, o principal segmento econômico desde o final do século XIX até 1960. Foram, entretanto, superados temporariamente pela empresa extrativista mercantil, que, por dois períodos - do final do século XIX a 1915, aproximadamente, e no primeiro qüinqüênio da década de 40 -, demandou as matas xinguanas em busca da borracha e do caucho.

Nesses períodos, o extrativismo mercantil engajou em suas atividades muitos criadores e camponeses em geral que habitavam os campos do Pau D'Arco. Além disso, com a monetarização que se registrou nessas épocas, e com a grande onda migratória verificada, formou-se um bom mercado para a venda do gado do lugar, o que foi fundamental para a sobrevivência da economia pastoril, pelo menos nos primeiros tempos.

Esse era em suma o quadro em que se inseriam os caucheiros da mata geral. Passada a fase extrativista, a economia pecuária assume novamente um lugar predominante nos campos do Pau D'Arco.

Apesar da ausência de mercado, em razão do reduzido número de habitantes nos campos e na cidade de Conceição e principalmente da falta de vias de escoamento da produção, o gado ainda era o único meio de se conseguir algum dinheiro para fazer face às necessidades não supridas pela economia pastoril.

No período analisado, o gado não tinha praticamente nenhum valor. Excluindo-se a fase de coleta da borracha e, em menor escala, após 1950, quando uma indústria de Araguacema, localizada na margem goiana do Araguaia, inicia a exportação de carne bovina para Belém em aviões, toda a história dos criadores do Pau D'Arco caracterizou-se por uma marginalização singular.

Para que se tenha uma idéia dessa situação e do baixo valor atribuído ao gado local, leia-se o depoimento de uma informante entrevistada em Redenção, que em 1964 foi a Conceição do Araguaia para submeter-se a uma cesariana: 
Naquele tempo o gado não valia nada. O preço do gado era nada. Nós vendemos bastante gado para poder pagar o parto. Tivemos que vender cinco novilhas e uma besta para poder pagar o parto e as despesas. O gado não tinha valor nenhum, agora é que está mais valorizado.

Note-se que isso se deu em 1964, quando a frente capitalista já ensaiava as primeiras mudanças no cenário econômico e social da região.

\section{Conclusões}

A análise histórica da ocupação da região do Araguaia paraense no período analisado permite que se chegue a algumas conclusões. A primeira refere-se ao fato de que o processo que extinguiu o índio de uma região periférica brasileira, incorporando as terras tribais à sociedade nacional e colocando-as a serviço da economia de subsistência pastoril na região do Pau D'Arco, também ocorreu no centro dinâmico da economia do país, que nessa época (final do século XIX) tinha no café seu principal meio de acumulação. Isso porque, tanto no CentroSul como na região analisada, as frentes de penetração aniquilaram populações tribais de mesma língua, os Kaiapó meridionais e os KayapóKradaú do Pau D'arco, respectivamente. A única diferença, quiçá, é que, no primeiro caso, tratava-se da expansão da fronteira capitalista dominante e, no segundo, da ampliação da fronteira camponesa pastoril de subsistência.

Como se viu, os Kayapó-Kradaú que habitavam os campos naturais, propícios para a criação bovina, foram rapidamente desalojados de sua moradia habitual e levados ao extermínio pela ação disseminadora do contato com a civilização.

A segunda conclusão é que, decorridos poucos anos desde o início da conversão das terras indígenas em fronteira camponesa produtora de valores de uso, o capital industrial europeu e norte-americano, pela forte demanda por borracha, determinou a expansão da fronteira extrativista mercantil, por meio da incursão nas áreas de floresta densa em direção ao rio Xingu e da instalação do capital comercial na região, o que provocou a criação de vários povoados na rota do caucho, a monetarização da economia, a formação de mercado, o desenvolvimento do comércio nos campos e, enfim, uma dinamização das atividades econômicas e sociais naquela área da Amazônia Oriental.

Finalmente, pode-se ainda concluir que esse mesmo capital industrial também determinou a estagnação econômica posterior e o regresso predominante do segmento pastoril de subsistência, durante meio século naquela região amazônica, na medida em que a produção de seringueiras cultivadas na Malásia e no Ceilão, fruto de investimentos em pesquisa incentivada pelos capitais industriais britânicos, inviabilizou a continuidade da indústria extrativa da borracha amazônica, em função da queda vertiginosa dos preços da goma no mercado internacional. 


\section{REFERÊNCIAS}

AUDRIN, José Maria. Entre sertanejos e índios do norte: O Bispo missionário Dom Domingos Carrerot. Rio de Janeiro: Ed. Púgil Ltda./ Livraria Agir Editora,1946.

BELLIZI, Ataliba Macieira. Pesquisas Antropométricas nos índios Mawé, Karajá e Kayapó. Rio de Janeiro: SEDREGA, 1958.

FURTADO, Celso. Formação Econômica do Brasil. São Paulo: Cia. Editora Nacional, 15ª edição, 1977.

IANNI,Octávio. A luta pela terra. Petrópolis: Editora Vozes, 1978.

IGLÉSIAS, Francisco. Catinga e Chapadões. São Paulo: Companhia Editora Nacional, Coleção Brasiliana nº 271, 2 a . Edição, 2 vls., 1958.

LUZ, Isaú Coelho. Rastros e Pegadas. Goiânia: Editora Kelpes, 2004.

MAGALHÃES FILHO, Francisco de B.B. de. História Econômica. São Paulo: Sugestões Literárias, $3^{a}$ edição, 1975.

MARTINELLO, Pedro. A Batalha da Borracha durante a Segunda Guerra Mundial. Rio Branco: Cadernos UFAC, série Estudos e Pesquisas 1, 1988.

MOREIRA NETO, Carlos Araújo. "A cultura pastoril do Pau D'arco". Belém: Boletim do Museu Paraense Emílio Goeldi. no 10. Nova Série, INPA, CNPq. março, 1960.

VELHO, Otávio Guilherme. Frentes de Expansão e Estrutura agrária. Rio de Janeiro: Zahar Editores, 1972. 